\title{
Effect of Center-Pivot Irrigation in the Rust and Brown Eye Spot of Coffee
}

\author{
Adriano Augusto de Paiva Custódio, Plant Protection Area, Agricultural Research Institute of Paraná, CEP 86047-902, Londrina, PR, \\ Brazil; and Edson Ampélio Pozza, Department of Phytopathology, Anselmo Augusto de Paiva Custódio, Department of Engineering, \\ Paulo Estevão de Souza, Department of Phytopathology, and Luiz Antônio Lima and Antônio Marciano da Silva, Department of \\ Engineering, Federal University of Lavras, CEP 37200-000, Lavras, MG, Brazil
}

\begin{abstract}
de Paiva Custódio, A. A., Pozza, E. A., de Paiva Custódio, A. A., de Souza, P. E., Lima, L. A., and da Silva, A. M. 2014. Effect of center-pivot irrigation in the rust and brown eye spot of coffee. Plant Dis. 98:943-947.

Incidence of rust (caused by Hemileia vastatrix) and brown eye spot (caused by Cercospora coffeicola) of coffee was evaluated for 2 years in southern Minas Gerais, Brazil, in a center-pivot-irrigated coffee crop with different water application levels. Treatments consisted of six water levels of 0 (nonirrigated), 60, 80, 100, 120, and 140\% applied according to class A evaporation pan (CAE). Progress of disease was influenced significantly by different water levels; the highest incidence of rust occurred with lower water levels- 0 (nonirrigated), 60, and

80\% CAE - whereas the lowest incidence was detected with larger water levels: 120 and 140\% CAE. There was one peak of rust incidence in August. The highest incidence of brown eye spot occurred with water levels of 100 and $140 \% \mathrm{CAE}$ and the lowest incidence was found in the nonirrigated treatment. Two incidence peaks occurred in March and June. This study identified that irrigation methods and water levels can decisively affect the epidemiological behavior of diseases and, therefore, their management.
\end{abstract}

Brazil is the world's largest producer of coffee (Coffea arabica L.) and the second largest consumer market. In addition, coffee is largely consumed worldwide. In this country, the state of Minas Gerais is responsible for approximately $50 \%$ of the national output, with the largest planted area in the state's southern region (8). In all, $25 \%$ of Brazilian coffee production comes from irrigated areas, although irrigated crops only cover 240,000 ha or $10 \%$ of the total area (8). Rainfall in southern Minas Gerais is favorable for coffee production but adverse weather causing droughts and a growing need for increased crop yield and quality of coffee due to global demand have encouraged producers to use irrigation in the region $(4,15)$. Despite the benefits, irrigated coffee production can intensify diseases such as rust (caused by Hemileia vastatrix Berk. \& Broome) and brown eye spot (caused by Cercospora coffeicola Berk. \& Cooke), causing significant losses $(19,20,23)$.

Water supplied by irrigation, especially with sprinkler systems such as center-pivot irrigation, can modify crop microclimate, increasing leaf wetness period and relative humidity and reducing canopy temperature and, thus, influencing progress of foliar diseases in various crops $(2,17,21,25)$. Unlike sprinkler irrigation, the drip method does not increase the number of hours of leaf wetness, thus reducing the progress rate of foliar diseases $(22,27)$ such as rust and brown eye spot of coffee $(19,20,23)$.

The influence of center-pivot irrigation in increasing rust and brown eye spot in another coffee-producing region in western Minas Gerais has been reported $(3,12)$; however, water level was assessed at only $100 \mathrm{~mm} \mathrm{month}^{-1}$ in these studies. Furthermore, little is known about the behavior of these diseases under center-pivot systems with different water levels in the major coffee-producing region in the country. Thus, the focus of this research was to study the progress of diseases over time and the effective management of irrigation water to identify alternatives capable of reducing fungicide use as well as increasing environmental and economic sustainability in agroecosystems.

Corresponding author: E. A. Pozza, E-mail: eapozza@dfp.ufla.br

Accepted for publication 21 January 2014.

http://dx.doi.org/10.1094/PDIS-07-13-0801-RE

(C) 2014 The American Phytopathological Society
In this study, it was hypothesized that center-pivot irrigation with different water levels modifies the progression of rust and brown eye spot of coffee. Therefore, the objective of this study was to evaluate the incidence of diseases in a center-pivot-irrigated coffee crop with different water application levels.

\section{Materials and Methods}

Experimental field and treatments. The study was conducted for 2 years, from 2004 to 2005 and from 2005 to 2006, at latitude $21^{\circ} 13^{\prime} 43^{\prime \prime}$ south, longitude $44^{\circ} 58^{\prime} 38^{\prime \prime}$ west, and an altitude of 918 $\mathrm{m}$, in Lavras state of Minas Gerais, Brazil. The region has a subtropical climate. The climatic classification proposed by Köppen is Cwa type with dry winters and rainy summers (6). The rainy season occurs from October to March (hydric excess of $661 \mathrm{~mm}$ ) while the dry season occurs from April to September (hydric deficiency of $30 \mathrm{~mm}$ ). The annual average temperature is $19.4^{\circ} \mathrm{C}$, ranging from $15.8^{\circ} \mathrm{C}$ in July to $22.1^{\circ} \mathrm{C}$ in February, and annual average total rainfall is $1,530 \mathrm{~mm}$, ranging from $23 \mathrm{~mm}$ in July to $296 \mathrm{~mm}$ in December (6). The soil is classified as Oxisol (eutroferric Red Latosol) with a north-south slope of $14 \%$. Soil texture in the layer from 0 to $25 \mathrm{~cm}$ is $76 \%$ clay, $22 \%$ sand, and $2 \%$ silt, with average bulk density of $1.29 \mathrm{~g} \mathrm{~cm}^{-3}$ and particle density of $2.67 \mathrm{~g} \mathrm{~cm}^{-3}$ $(11,15)$. Coffee plants were grown conventionally but without fungicide application. Fertilization was performed according to chemical analysis of the soil and leaf $(11,15)$. The variety of Coffea arabica L. was 'Rubi MG 1192', which is susceptible to rust and brown eye spot. Level planting was conducted in March 1999 $(11,15)$ with 3.50 -by-0.80-m spacing $\left(3,571\right.$ plants ha $\left.{ }^{-1}\right)$ in a randomized complete block design with three replicates. Treatments were made at six water levels of 0 (nonirrigated control treatment), $60,80,100,120$, and $140 \%$ applied according to class A evaporation pan (CAE) $(11,15)$. The area enclosed by the center pivot was divided into segments of $20^{\circ}$ composed of plots with eight-plant rows. The center-pivot speed was adjusted to achieve the different water level treatments $(11,15)$. The center-pivot speed was highest in the treatments $80 \%(+20 \%)$ and $60 \%$ CAE $(+40 \%)$ compared with treatment $100 \% \mathrm{CAE}(0.26 \mathrm{~km} / \mathrm{h})$ and lowest in the treatments $120 \%(-20 \%)$ and $140 \%$ CAE $(-40 \%)$. In the nonirrigated control treatment, the central pivot moved over the plots without applying water.

Irrigation and climatic data. Center-pivot irrigation started in 1999 at planting time in a 1.6-ha area with $71.5-\mathrm{m}$ wetted radius. The center pivot was fitted with diffusers spaced $2.20 \mathrm{~m}$ apart, $2 \mathrm{~m}$ 
from the canopy. CAE was monitored daily (in millimeters) for calculating the water levels to be applied $(11,15)$. Irrigation interval was fixed at 2 and 3 days. The irrigation time was $1.43 \mathrm{~h}$ by day in the whole area. The irrigation time was lowest in the treatments $80 \%(-20 \%)$ and $60 \%(-40 \%)$ CAE compared with treatment $100 \%$ CAE $(0.29 \mathrm{~h})$ and highest in the treatments $120 \%(+20 \%)$ and $140 \%(+40 \%)$ CAE. On rainy days, irrigation needs were estimated from the balance between total precipitation and CAE (in millimeters) $(11,15)$. Climatic variables were obtained from the major weather station in Lavras, the 5th District of Instituto Nacional de Meteorologia, located $380 \mathrm{~m}$ from the experimental site. Data correspond to daily averages of precipitation (in millimeters), relative humidity (\%), and maximum and mean temperature $\left({ }^{\circ} \mathrm{C}\right)$. Daily values were provided by four weather observations for the period between assessments of disease, according to the Greenwich Mean Time (Fig. 1). During both study periods, from 2004 to 2006, and the previous year, from 2003 to 2004, water levels were measured for each treatment plus annual rainfall (in millimeters) (Table 1). The nonirrigated control treatment (0\% CAE) received only precipitation whereas, in the other treatments, CAE values were added, corrected by factors $0.6(60 \%), 0.8(80 \%), 1.0(100 \%)$ $1.2(120 \%)$, and $1.4(140 \%$ CAE) $(11,15)$.

Assessment of disease and yield. The incidence of rust and brown eye spot of coffee was assessed at 23-day intervals $(13,14)$ beginning on 14 April 2004 and ending on 1 June 2006. The first assessment period (year 1) was April 2004 to April 2005 and the second period (year 2) was May 2005 to July 2006. A nondestructive evaluation method was used, where eight coffee leaves per plant, four from each side of the plant or from the side facing the sun, were taken at random between the third and fourth pairs of plagiotropic branches in the middle third of the plant. Diseases were evaluated in eight viable plants in each experimental plot. Thus, 64 leaves were sampled per plot at each assessment date. The incidence of rust and brown eye spot was calculated by divid-
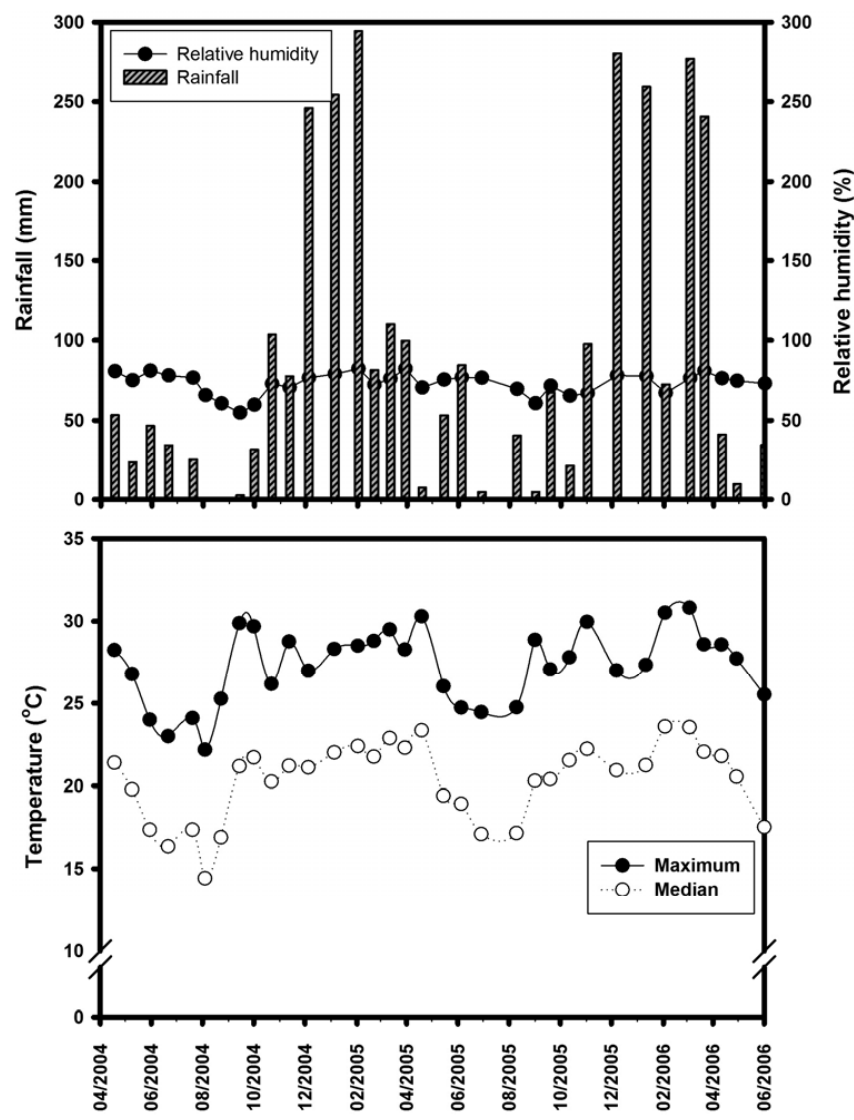

Fig. 1. Climatic variables, April 2004 to June 2006. Year 1, April 2004 to April 2005. Year 2, May 2005 to June 2006. ing the number of damaged leaves by total sample (18). The average incidence of 34 assessments on the progress of the diseases were plotted for their temporal progress (18). The area under the disease progress curve (AUDPC) was calculated (24). Yield (in kilograms per hectare) was estimated during the study period from 2004 to 2005 (year 1) and from 2005 to 2006 (year 2), and the previous year from 2003 to 2004 (11,15; Table 1). Fruit of the eight viable plants were picked and their volume was recorded. After homogenization, we collected 10-liter samples, which were then dried until reaching moisture contents of $11 \%$. Subsequently, samples were processed and weighed, and plot yield was estimated $(11,15)$.

Statistical analysis. AUDPC and yield were subjected to analysis of variance using PROC GLM of SAS (version 8.1; SAS Institute). Significant treatments $(P<0.05)$ were compared using Tukey's honestly significant difference test. Regression analysis and fitting of linear models (PROC REG) were performed for water levels. Correlation analysis (PROC CORR) was performed between the water level applied to each treatment plus annual rainfall and plant yield with AUDPC in both years of disease evaluation, from 2004 to 2005 (year 1) and from 2005 to 2006 (year 2), using Pearson's correlation test to estimate relationship with treatments. Prior to statistical analysis, the original data were subjected to the Shapiro-Wilk test for normality of residuals and Bartlett's test for homogeneity of variances. According to these tests, no data transformation was needed.

\section{Results}

Rust. Regarding temporal progress of disease, the highest incidence occurred between July and August in the first year. During this period, the highest incidence occurred in August in most treatments, up to $26 \%$ above the nonirrigated treatment and $80 \%$ CAE (Fig. 2). Between July 2004 and August 2004, average maximum temperature was $24^{\circ} \mathrm{C}$. Also, low rainfall was recorded, with an average of $8 \mathrm{~mm}$ (Fig. 1). The second assessment year had slower disease progress. The highest incidence occurred between June and August, with a maximum of $8 \%$ in the $60 \%$ CAE treatment in July (Fig. 2). Between June 2005 and August 2005, maximum temperature was $25^{\circ} \mathrm{C}$ and average rainfall was $15 \mathrm{~mm}$ (Fig. 1).

Based on the rust AUDPC, the water levels were significantly different and treatments modified disease progress in the canopy. In the first assessment year, the third-degree polynomial provided a good fit, with the highest rust AUDPC occurring in the nonirrigated treatment and in water levels 60, 80, and 100\% CAE. The

Table 1. Center-pivot water levels (WL) plus annual rainfall (W) in millimeters and coffee yield $(\mathrm{Y})$ in kilogram per hectare in previous years (from 2003 to 2004) and during disease assessment (from 2004 to 2005 and from 2005 to 2006) in the field per treatment ${ }^{\mathrm{a}}$

\begin{tabular}{lcccc}
\hline $\begin{array}{l}\text { WL } \\
(\mathbf{\%} \text { CAE) }\end{array}$ & W and Y & $\begin{array}{c}\text { Previous } \\
(\mathbf{2 0 0 3 - 0 4 )}\end{array}$ & $\begin{array}{c}\text { Year 1 } \\
(\mathbf{2 0 0 4}-\mathbf{0 5})\end{array}$ & $\begin{array}{c}\text { Year 2 } \\
(\mathbf{2 0 0 5}-\mathbf{0 6})\end{array}$ \\
\hline 0 & W & $1,220.40$ & $1,438.70$ & $1,589.20$ \\
& Y & $3,060.00$ & $1,572.00$ & $1,770.00$ \\
60 & W & $2,230.90$ & $2,425.60$ & $2,678.30$ \\
& Y & $2,880.00$ & $1,746.00$ & $1,866.00$ \\
80 & W & $2,567.70$ & $2,754.60$ & $3,041.40$ \\
& Y & $1,518.00$ & $1,728.00$ & $1,812.00$ \\
100 & W & $2,904.60$ & $3,083.60$ & $3,404.40$ \\
& Y & $2,454.00$ & $1,188.00$ & $2,418.00$ \\
120 & W & $3,241.40$ & $3,412.50$ & $3,767.40$ \\
& Y & $1,890.00$ & $1,224.00$ & $1,650.00$ \\
140 & W & $3,578.20$ & $3,741.50$ & $4,130.50$ \\
& Y & $2,064.00$ & $1,596.00$ & $1,248.00$ \\
\hline
\end{tabular}

${ }^{\mathrm{a}}$ Previous $=1$ year prior to disease assessment, 19 April 2003 to 17 April $2004(18,25)$. Year $1=2004$ to 2005 and Year $2=2005$ to 2006; total disease assessment in the field occurred 17 April 2004 to 1 June 2006.

b Treatments with WL, percentage applied according to class A evaporation pan (CAE). In nonirrigated control treatment ( $0 \%$ CAE), W corresponds only to precipitation values whereas, in other treatments, CAE values are added to W, corrected by factors $0.6(60 \%), 0.8(80 \%) 1.0(100 \%) 1.2$ $(120 \%)$, and 1.4 (140\% CAE).

${ }^{c}$ Nonsignificant $P>0.05$. 
lowest AUDPC occurred in water levels 120 and 140\% CAE (Fig. $3 \mathrm{~A})$. In the second year, the first-degree equation gave the best fit, with the highest rust AUDPC occurring in the nonirrigated treatment and in $60 \% \mathrm{CAE}$ water level. The lowest AUDPC occurred in the highest water levels, 120 and 140\% CAE (Fig. 3A).

Brown eye spot. Regarding temporal progress of disease, in both years, two peaks of incidence were recorded in the irrigated

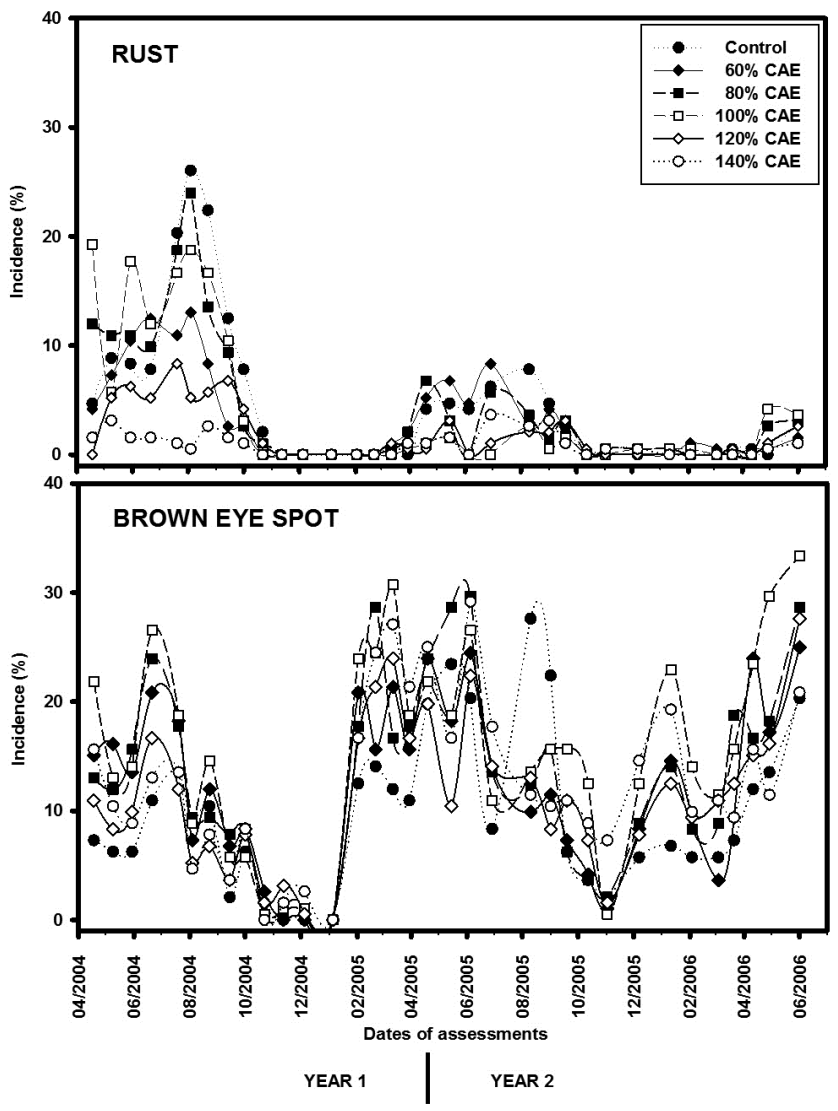

Fig. 2. Temporal progress of rust and brown eye spot in center-pivot-irrigated coffee, April 2004 to June 2006. Year 1, April 2004 to April 2005. Year 2, May 2005 to June 2006. treatments, in March and June of each year. Incidence of brown eye spot was higher in the second year, with the highest incidence between May and July (Fig. 2). In the first year, 100\% CAE water level had an incidence of 27\% in July 2004 and 24\% in February 2005 (Fig. 2). February 2005 had an average temperature of $22^{\circ} \mathrm{C}$, high-accumulated rainfall of $295 \mathrm{~mm}$, and relative humidity increased to $82 \%$ (Fig. 1). An incidence of $31 \%$ was recorded in March 2005 at the water level 100\% CAE. In the second year, there was higher disease incidence in the irrigated treatments. A maximum incidence of $33 \%$ was recorded with water level $100 \%$ CAE in the last evaluation, June 2006. In the first four assessments of the second year, between May and August 2005, there were incidences of up to $30 \%$ in $80 \%$ CAE water level and $8 \%$ in the nonirrigated treatment in June 2005 (Fig. 2). During this period, the average temperature was $18^{\circ} \mathrm{C}$, accumulated rainfall was 183 $\mathrm{mm}$, and average relative humidity $75 \%$ (Fig. 1).

Brown eye spot was influenced by different water levels. In the first year, the second-degree equation provided the best fit. The control treatment had the lowest AUDPC, which increased up to $100 \%$ CAE water level then decreased in $120 \%$ CAE water level but still remained high compared with the control treatment. In the second year, AUDPC values were, on average, 33\% higher than in the previous year and increased linearly with increasing water levels (Fig. 3B).

Correlation. There was a significant positive correlation between crop yield from 2003 to 2004 and incidence of rust (AUDPC) at water levels 0 and $100 \%$ CAE (year 1) and 60\% CAE (year 2), with high correlation coefficients $(r=0.99$; Table 2). Thus, in the same year, increased rust in the field was directly proportional to crop yield increase. Positive correlation $(r=0.99)$ was also found between applied water levels plus annual precipitation and brown eye spot AUDPC (year 1) in 140\% CAE water level from 2003 to 2004 and AUDPC (year 2) in 120\% CAE water level from 2003 to 2004, from 2004 to 2005, and from 2005 to 2006. In these treatments, increasing applied water levels plus annual precipitation resulted significantly in increased brown eye spot (Table 2).

\section{Discussion}

Rust. The rust progress curve varied between assessment years in the irrigated and nonirrigated treatments. All treatments, especially the nonirrigated and 60, 80, and 100\% CAE water levels, had a higher incidence between July and August and a single peak
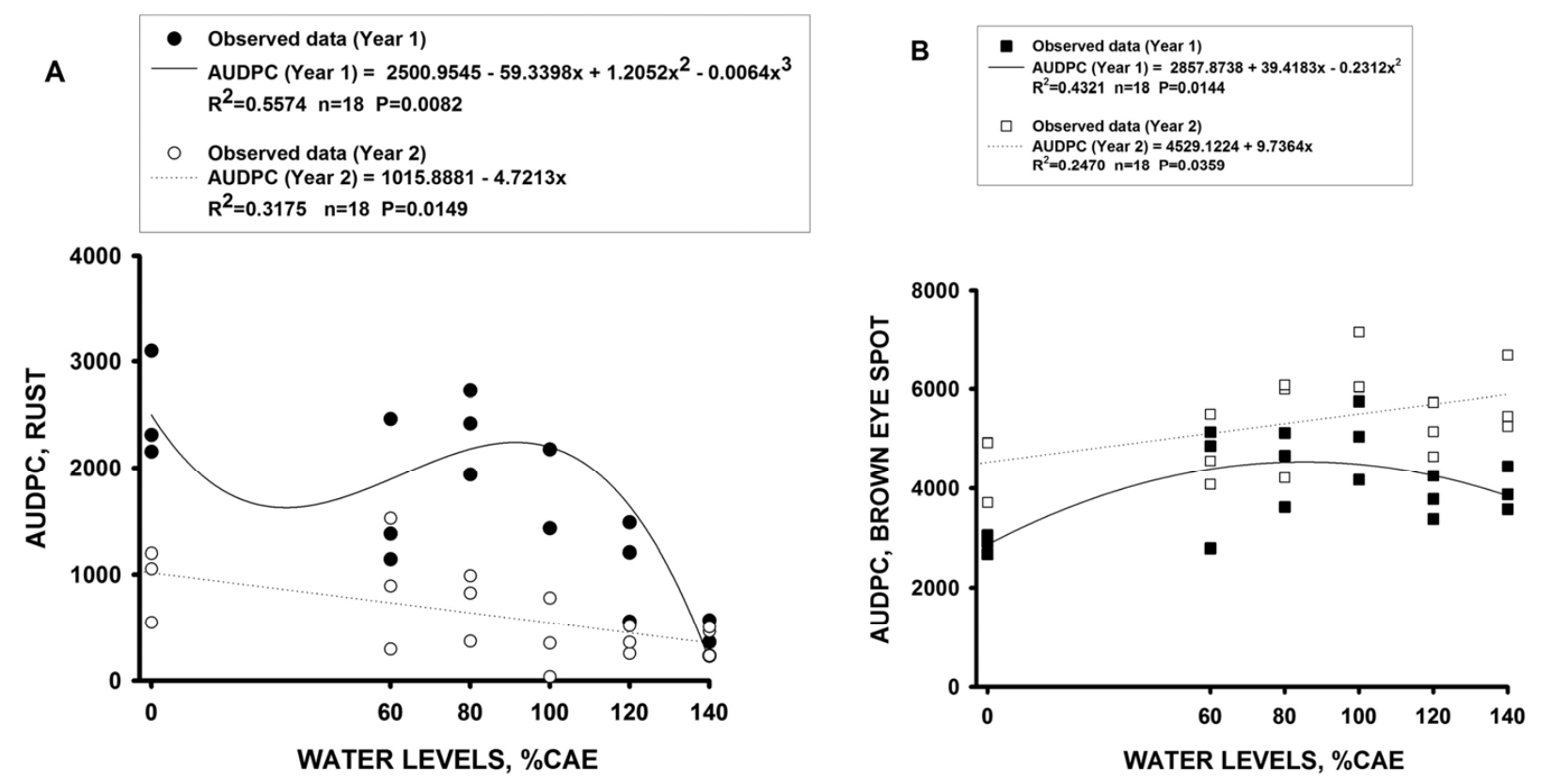

Fig. 3. Area under disease progress curve (AUDPC). A, Rust and B, brown eye spot in coffee crops with different water levels, center pivot. Year 1, April 2004 to April 2005. Year 2, May 2005 to June 2006. 
incidence per year in August (Fig. 2). With regard to periods of greater incidence in irrigated crops, different results have been found among various authors. In a center-pivot-irrigated crop in western Minas Gerais, Carvalho (3) found a higher incidence of disease between July and August as in our study. Miranda et al. (19) also found similar results in a drip-irrigated crop in southern Minas Gerais. However, in the same location of our experiment in southern Minas Gerais, Boldini (1) and Santos (22) found maximum incidence between June and July in a drip-irrigated crop, whereas Talamini et al. (26) reported a higher incidence of disease between July and September. Therefore, the period of highest incidence of coffee rust should be between June and September, depending on factors such as the annual weather, crop yield, cultivation methods, and crop management.

With regard to rust increase with increasing water level up to 80\% CAE (year 1) and drop in AUDPC in the highest water levels (120 and $140 \%$ CAE in both years), our results are not in agreement with those reported in field studies. In western Minas Gerais, Brazil, from 1997 to 1998, Carvalho (3) reported increased incidence of rust in a center-pivot-irrigated area with a single water level $\left(100 \mathrm{~mm} \mathrm{month}^{-1}\right)$ compared with either a drip-irrigated field $\left(60,80\right.$, and $\left.100 \mathrm{~mm} \mathrm{month}^{-1}\right)$ or a nonirrigated area, due to increased leaf wetness period. Several authors such as Talamini et al. (27) from 1998 to 1999, Boldini (1) from 1999 to 2000, Santos (22) from 2000 to 2001, and Miranda et al. (19) from 2002 to 2003 found no influence of increased water level $(0,40,60,80$, and $100 \%$ CAE) on rust incidence in drip-irrigated 'Acaiá Cerrado' coffee planted in March 1997. According to the authors, drip irrigation does not increase leaf wetness period, which is favorable for $H$. vastatrix germination.

However, our results agree with the study of Gomes et al. (11) conducted in the same area as this study. The authors noted that, from 2001 to 2002, water levels above $100 \%$ CAE produced low incidence of rust. This may be due to several factors, such as larger crop load in treatments with high incidence of disease in previous years $(11,15)$ or removal of urediniospores from leaves due to excess water $(13,14)$. With regard to crop load, in the first assessment year, a significant positive correlation was found from 2003 to 2004 in water levels 0 (nonirrigated) and $100 \%$ CAE (Table 2) with higher incidence of rust in the field (Fig. 2). In the second assessment year, significant positive correlation was found from 2003 to 2004 in water level $60 \%$ (Table 2) with higher incidence of rust (Fig. 2). These treatments had higher crop yield in previous years. A positive correlation between rust and crop yield has been reported (5). Thus, it is understandable that the AUDPC is higher in both nonirrigated treatment and water level 100\% CAE in the first year, as well as in $60 \%$ CAE water level in the second assessment year (Table 2), because previous years' high crop load $(11,15)$ led to imbalance due to nutrient drain, thus predisposing plants to infection by $H$. vastatrix, a factor in determining the intensity of rust (5). In addition, leaf vibrations caused by impact of water may release urediniospores, which are then deposited on the ground (9). This may have provided less inoculum for coffee leaves in irrigated treatments, thus reducing rust $(13,14)$. The fact that control treatment and water levels 60, 80, and $100 \%$ CAE show a higher AUDPC is clearly linked to higher yield and lower amount of inoculum, as observed in the correlation analysis and by other authors $(13,14)$.

Brown eye spot. Center-pivot-irrigated treatments had two peaks of incidence over time, in March and June. The highest incidence occurred between May and July (Fig. 2), when weather was favorable for disease $(7,16)$. These results differ from those found by Talamini et al. (26,27), Boldini (1), and Santos et al. (23) in drip-irrigated coffee in southern Minas Gerais. According to the authors, although maximum incidence of brown eye spot occurred between May and July, only a single peak was recorded. Thus, it was possible to note that center-pivot sprinkler irrigation changed the behavior of the progress curve of brown eye spot in coffee. The

Table 2. Pearson's correlation coefficients between water levels (WL) applied to each treatment plus annual rainfall (W), coffee yield (Y), and area under the disease progress curve (AUDPC) of rust and brown eye spot in the first (year 1) and second (year 2) assessment year for each center-pivot WL ${ }^{\mathrm{a}}$

\begin{tabular}{|c|c|c|c|c|c|c|}
\hline \multirow[b]{2}{*}{ WL $(\% \text { CAE })^{\mathrm{d}}$} & \multirow[b]{2}{*}{$W$ and $Y$} & \multicolumn{2}{|c|}{ AUDPC (year 1) ${ }^{\mathbf{b}}$} & \multicolumn{3}{|c|}{ AUDPC (year 2) } \\
\hline & & 2003-2004 & 2004-2005 & $2003-2004$ & 2004-2005 & 2005-2006 \\
\hline \multicolumn{7}{|l|}{ Rust } \\
\hline \multirow[t]{2}{*}{0} & W & -0.93 & -0.93 & 0.74 & 0.74 & 0.74 \\
\hline & Y & $0.99 *$ & -0.46 & -0.92 & 0.11 & -0.96 \\
\hline \multirow[t]{2}{*}{60} & $\mathrm{~W}$ & -0.77 & -0.75 & 0.52 & 0.54 & 0.56 \\
\hline & $\mathrm{Y}$ & 0.19 & 0.63 & $0.99 *$ & 0.86 & 0.55 \\
\hline \multirow[t]{2}{*}{80} & W & 0.53 & 0.66 & 0.34 & 0.19 & 0.11 \\
\hline & $\mathrm{Y}$ & 0.99 & -0.54 & -0.70 & -0.33 & -0.61 \\
\hline \multirow[t]{2}{*}{100} & W & 0.63 & 0.56 & 0.49 & 0.41 & 0.57 \\
\hline & $\mathrm{Y}$ & $0.99 *$ & -0.70 & 0.98 & -0.82 & 0.29 \\
\hline \multirow[t]{2}{*}{120} & W & 0.67 & 0.64 & 0.60 & 0.64 & 0.67 \\
\hline & $\mathrm{Y}$ & 0.06 & -0.93 & 0.97 & 0.53 & 0.15 \\
\hline \multirow[t]{2}{*}{140} & W & 0.68 & 0.58 & -0.05 & -0.17 & -0.20 \\
\hline & $\mathrm{Y}$ & -0.94 & -0.97 & -0.89 & -0.83 & -0.99 \\
\hline \multicolumn{7}{|l|}{ Brown eye spot } \\
\hline \multirow[t]{2}{*}{0} & W & 0.61 & 0.61 & -0.87 & -0.87 & -0.87 \\
\hline & $\mathrm{Y}$ & -0.84 & -0.06 & 0.66 & -0.98 & 0.02 \\
\hline \multirow[t]{2}{*}{60} & $\mathrm{~W}$ & 0.80 & 0.79 & -0.65 & -0.63 & -0.61 \\
\hline & $\mathrm{Y}$ & -0.13 & -0.58 & 0.35 & 0.75 & -0.62 \\
\hline \multirow[t]{2}{*}{80} & W & 0.61 & 0.72 & 0.80 & 0.88 & 0.91 \\
\hline & $\mathrm{Y}$ & 0.98 & -0.62 & 0.88 & -0.80 & 0.94 \\
\hline \multirow[t]{2}{*}{100} & W & 0.64 & 0.70 & 0.81 & 0.75 & 0.86 \\
\hline & $\mathrm{Y}$ & -0.18 & 0.83 & 0.97 & -0.51 & -0.14 \\
\hline \multirow[t]{2}{*}{120} & $\mathrm{~W}$ & 0.45 & 0.41 & $0.99^{*}$ & $0.99 *$ & $0.99 *$ \\
\hline & $\mathrm{Y}$ & -0.21 & -0.99 & 0.79 & -0.33 & 0.87 \\
\hline \multirow{2}{*}{140} & W & $0.99 *$ & 0.98 & -0.88 & -0.94 & -0.95 \\
\hline & $\mathrm{Y}$ & -0.47 & -0.58 & -0.08 & 0.06 & -0.44 \\
\hline
\end{tabular}

${ }^{\text {a }}$ From 2003 to 2004 = 1 year prior to disease assessment (18,25); from 2004 to 2005 (year 1) and from 2005 to 2006 (year 2) = during disease assessment in the field; $*=$ high significance level at $P<0.05$.

b AUDPC in the first year, April 2004 to April 2005 (year 1).

${ }^{c}$ AUDPC in the second year, May 2005 to June 2006 (year 2).

${ }^{\mathrm{d}}$ Treatments with WL, percentage applied according to class A evaporation pan (CAE). W: in nonirrigated control treatment ( $0 \%$ CAE), W corresponds only to precipitation values whereas, in other treatments, CAE values are added to W, corrected by factors $0.6(60 \%), 0.8(80 \%) 1.0(100 \%) 1.2(120 \%)$, and 1.4 $(140 \%$ CAE). 
highest disease progress occurred between May and August in southern Minas Gerais.

The higher AUDPC of disease found in higher water levels disagrees with results obtained with increasing water level in drip irrigation $(26,27)$. A drip-irrigated coffee crop using water levels in the same location in southern Minas Gerais showed linear reduction of AUDPC with increasing water supply in water levels 0 (nonirrigated), 40, 60, 80, and 100\% CAE $(1,23)$. Even in higher water levels applied to the soil, drip irrigation provides shorter periods of leaf wetness compared with sprinkler irrigation (21), thus hindering spore germination. In western Minas Gerais, Juliatti et al. (12) found a higher incidence of disease in center-pivotirrigated treatments compared with drip irrigation, concluding that a longer leaf wetness period resulted in a favorable microclimate for brown eye spot. However, the study focused on a single water level, $100 \mathrm{~mm}$ month $^{-1}$.

Sprinkler irrigation definitely increased the AUDPC, although with differences in relation to water levels. This is apparent from the significant positive correlation between water levels plus rainfall and the brown eye spot in water levels 120 and 140\% CAE (Fig. 1; Table 2).

Center-pivot sprinkler irrigation changed the progress of rust and brown eye spot differently at different water levels. Possibly, microclimate change and inoculum deposition influenced different stages of host-pathogen relationships. Manipulation of the environment through farming practices that reduce the rate of polycyclic disease progress may be an important management strategy (18).

\section{Acknowledgments}

The research was funded by CBP \& Café, CNPq, CAPES, FAPEMIG, and INCT-Café. We thank L. A. A. Vilela (in memoriam) and N. M. Gomes for their encouragement, and M. L. Ellis for review of this manuscript.

\section{Literature Cited}

1. Boldini, J. M. 2001. Epidemiologia da ferrugem e da cercosporiose em cafeeiro irrigado e fertirrigado. M.S. thesis, Universidade Federal de Lavras, Campus Universitário, Minas Gerais, Brazil.

2. Browne, G. T., De Tar, W. R., Sanden, B. L., and Phene, C. J. 2002. Comparison of drip and sprinkler irrigation systems for applying metam sodium and managing stem rot on potato. Plant Dis. 86:1211-1218.

3. Carvalho, A. M. 1998. Progresso da ferrugem (Hemileia vastatrix) em diferentes sistemas de irrigação. B.S. thesis, Universidade Federal de Uberlândia, Campus Universitário, Minas Gerais, Brazil.

4. Coelho, G., Silva, A. M., Rezende, F. C., Silva, R. A., and Custódio, A. A. P. 2009. Efeito de épocas de irrigação e de parcelamentos de adubação sobre a produtividade do cafeeiro 'Catuaí'. Ciênc. Agrotec. 33:67-73.

5. Costa, M. J. N., Zambolim, L., and Rodrigues, F. A. 2006. Efeito de níveis de desbaste de frutos do cafeeiro na incidência da ferrugem, no teor de nutrientes, carboidratos e açúcares redutores. Fitopatol. Bras. 31:564-571.

6. Dantas, A. A. A., Carvalho, L. G., and Ferreira, E. 2007. Climatic classification and tendencies in Lavras region, MG. Ciênc. Agrotec. 31:1862-1866.

7. Echandi, E. 1959. La chasparria de los cafetos causada por el hongo Cercospora coffeicola Berk. \& Cooke. Turrialba 9:54-67.
8. Fernandes, A. L. T., Partelli, F. L., Bonomo, R., and Golynski, A. 2012. A moderna cafeicultura dos cerrados brasileiros. Pesq. Agropec. Trop. 42:231240.

9. Fitt, B. D. L., McCartney, H. A., and Walklate, P. J. 1989. The role of rain in dispersal of pathogen inoculum. Annu. Rev. Phytopathol. 27:241-270.

10. Gomes, N. M., Chalfoun, S. M., Martins, C. P., and Vilela, L. A. A. 2002 Evolução da ferrugem (H. vastatrix Berk. \& Br.) do cafeeiro (C. arabica L.) sob diferentes regimes de irrigação por pivô central. Pages 222-224 in: Congr. Br. Pesq. Caf. Caxambu, MG, Brazil.

11. Gomes, N. M., Lima, L. A., and Custódio, A. A. P. 2007. Crescimento vegetativo e produtividade do cafeeiro irrigado no sul do Estado de Minas Gerais. Rev. Bras. Eng. Agríc. Ambient. 11:564-570.

12. Juliatti, F. C., Silva, A. da, Peixoto, A. S., Moreira, J. C., and Santos, C. M. dos. 1998. Incidência de Cercospora coffeicola no café irrigado de Araguari-MG. Pages 212-213 in: Congr. Br. Pesq. Caf. Poços de Caldas, MG, Brazil.

13. Kushalappa, A. C., Akutsu, M., and Ludwig, A. 1983. Application of survival ratio for monocyclic process of Hemileia vastatrix in predicting coffee rust infection rates. Phytopathology 73:96-103.

14. Kushalappa, A. C., and Eskes, A. B. 1989. Advances in coffee rust research. Annu. Rev. Phytopathol. 27:503-531.

15. Lima, L. A, Custódio, A. A. P., and Gomes, N. M. 2008. Produtividade e rendimento do cafeeiro nas cinco primeiras safras irrigado por pivô central em Lavras, MG. Ciênc. Agrotec. 32:1832-1842.

16. López-Duque, S., and Fernández-Borrero, O. 1969. Epidemiologia de la mancha de hierro del cafeto (Cercospora coffeicola Berk. y Cook.). Cenicafé 20:3-19.

17. Ludy, R. L., Powelson, M. L., and Hemphill Jr, D. D. 1997. Effect of sprinkler irrigation on bacterial soft rot and yield of broccoli. Plant Dis. 81:614 618.

18. Madden, L. V., Hughes, G., and van den Bosch, F. 2007. The Study of Plant Disease Epidemics. American Phytopathological Society, St. Paul, MN.

19. Miranda, J. C., Souza, P. E., Pozza, E. A., Faria, M. A., Santos, F. S., Barreto, S. S., and Silva, M. L. O. 2006. Intensidade da ferrugem em cafeeiro fertirrigado. Ciênc. Agrotec. 30:885-891.

20. Paiva, B. R. T. L., Souza, P. E., Scalco, M. S., and Alvarenga, L. S. 2011. Progresso da ferrugem do cafeeiro irrigado em diferentes densidades de plantio pós-poda. Ciênc. Agrotec. 35:137-143.

21. Rotem, J., and Palti, J. 1969. Irrigation and plant diseases. Annu. Rev. Phytopathol. 6:267-288.

22. Santos, F. S. 2002. Progresso da ferrugem e da cercosporiose em cafeeiro (Coffea arabica L.) irrigado. M.S. thesis, Universidade Federal de Lavras, Campus Universitário, Minas Gerais, Brazil.

23. Santos, F. S, Souza, P. E., and Pozza, E. A. 2004. Epidemiologia da cercosporiose em cafeeiro (Coffea arabica L.) fertirrigado. Summa Phytopathol. 30:31-37.

24. Shaner, G., and Finney, R. E. 1977. The effect of nitrogen fertilization on the expression of slow-mildewing resistance in Knox wheat. Phytopathology 67:1051-1056.

25. Subbarao, K. V., Hubbard, J. C., and Schulbach, K. F. 1997. Comparison of lettuce diseases and yield under subsurface drip and furrow irrigation. Phytopathology 87:877-883.

26. Talamini, V., Pozza, E. A., Souza, P. E., and Silva, A. M. 2003. Progresso da ferrugem e da cercosporiose em cafeeiro (Coffea arabica L.) com diferentes épocas de início e parcelamentos da fertirrigação. Ciênc. Agrotec. 27:141149.

27. Talamini, V., Souza, P. E., Pozza, E. A., Silva, A. M., and Bueno Filho, J. S. S. 2001. Progresso da ferrugem e da cercosporiose do cafeeiro (Coffea arabica L.) em diferentes lâminas de irrigação e diferentes parcelamentos de adubação. Ciênc. Agrotec. 25:55-62. 